\title{
Heat treated wood-filled styrene maleic anhydride (SMA) copolymer
}

\section{composites}

\author{
Mustafa ZOR ${ }^{1 *}$, Alper KIZILTAS ${ }^{2}$, Lu WANG $^{2}$, Douglas J. GARDNER ${ }^{2}$ \\ ${ }^{1}$ University of Bulent Ecevit, Caycuma Vocational School, Interior Design Programme, Zonguldak, \\ TURKEY \\ ${ }^{2}$ University of Maine, School of Forest Resources, Advanced Structures and Composite Center, USA \\ *Corresponding author: mustafa.zor@beun.edu.tr
}

Received Date: 26.12.2017

Accepted Date: 02.08 .2018

Abstract

Aim of study: In this study, it was aimed to establish and optimize a production process for engineering thermoplastic composites based on heat treated wood fillers and SMA copolymer.

Material and Methods: As wood material, pine wood (Pinus strobus L.), and as a thermoplastic copolymer material, Styrene Maleic Anhydride (SMA) copolymer were used in this study. Heat treatment was conducted at $212^{\circ} \mathrm{C}$ for $8 \mathrm{~h}$ in an attempt to improve the durability of the wood furnish and the wood flour and SMA compounds were extruded and granulated using a lab-scale grinder. Physical test, mechanical test and morphological tests were calculated.

Main results: The results showed that the highest tensile strength was in the $30 \mathrm{wt} \%$ wood flour/SMA and it has been seen that the positive effect on FMOE,TMOE of heat treated wood flour/SMA. Weak interfacial bonding was observed between the polymer and wood filler from the SEM images of the fractured surfaces of wood flour/SMA composites.

Research highlights: The results from this research indicated the compatibility of the SMA copolymer with the wood flour and the changes in the mechanical strength of the material. Due to limited heat treated wood thermoplastic composite usage in the field of wood engineering, there is a need for more extensive work in the future.

Keywords: Wood flour, Styrene Maleic Anhydride, Characterization Analysis

\section{Isıl işlem odun dolgulu stiren maleik anhidrit kopolimer kompozitleri}

Özet

Çalışmanın amacı: Bu çalışmada, ısıl işlem odun dolguları ve SMA kompozitleri temelli mühendislik termoplastiklerinin üretim proseslerinin optimizasyonun belirlenmesi amaçlanmaktadır.

Materyal ve Yöntem: Ahşap malzeme olarak veymut çamı, termoplastik kopolimer olarak stiren maleik anhidrit çalışmada kullanılmıştır. Odun donatısının kararlılığını iyileştirmek için 8 saatlik $212^{\circ} \mathrm{C}$ 'de ısıl işlem metodu uygulandı ve SMA ile odun bileşenleri laboratuvar tipi öğütücüler kullanılarak kalıptan geçirildi. Fiziksel, mekanik ve morfolojik testler ölçüldü.

Sonuçlar: Yapılan çalışmalar sonucu en yüksek çekme direnç değeri \%30 odun SMA grubunda ve 1sıl işlemli odun unu SMA grubunun eğilmede ve çekmede elastikiyet modülü üzerine pozitif etkisi görülmüştür. Odun unu SMA grubunun kırılmış yüzey SEM görüntülerinden odun dolgusu ile polimer arasında zayıf arayüz bağları gözlemlenmiştir.

Araştırma vurguları: Bu araştırmanın sonuçları, mühendislik malzemesi olan SMA kopolimerinin odun unu ile uyumu ve malzemenin mekanik mukavemetindeki değişiklikleri göstermektedir. Ahşap mühendisliği alanında sınırlı 1sıl işlemli odun termoplastik kompozit kullanımı nedeniyle gelecekte daha kapsamlı çalışmalara ihtiyaç vardır.

Anahtar Kelimeler: Odun unu, Strien Maleik Anhidrit, Karakterizasyon Analizi

\section{Introduction}

Heat treatment on wood refers to a process where wood is subjected to a heat source, resulting in physical, chemical and mechanical changes (Ross, 2010). This process mainly removes the hemicelluloses portion of wood, reducing the total hydroxyl groups and resulting in a less hygroscopic material (Groot et al., 1988; Nebesarova, 1996). Basically, five different commercial 
heat treatments have revealed, one in Finland (ThermoWood), one in Holland (Platp Wpd), one in Germany (OHT-Oil Heat Treatment), and two in France (Bois Perdue and Rectification). This modification process is also utilized in other countries such as Denmark (WTT) and Austria (Huber Holz). When considered the wood species by the Finnish method (ThermoWood), they are usually Scots pine (Pinus sylvestris L.) and spruce (Picea abies) which are used in the exterior applications such as terraces, garden furniture, doors and window. Poplar (Populus tremula L.) and birch (Betula pendula) are also common ThermoWood that are also used for exterior applications (Esteves and Pereira, 2009). Thermal modification occurs step with peak temperatures between $180^{\circ} \mathrm{C}-260^{\circ} \mathrm{C}$ and the resulting materials properties demonstrate variability depend on duration of treatment, temperature, wood species and treatment atmosphere (Hill, 2006). Previous studies on heat treated wood revealed decreased hygroscopicity and improved dimensional stability and biological resistance without contaminating the environmental (Tuong and $\mathrm{Li}$, 2010). Marcos and Hale, (2009) investigated the effect of chemical changes on the wood-moisture relationships in thermally modified wood and found that most wood-moisture properties were strongly correlated with changes in chemical constituent in thermally modified wood. The decreased moisture uptake of heat treated wood was mainly due to the degradation of hemicelluloses and reduction of free hydroxyl groups. Ayrilmis et al. (2011) studied the effect of thermal treatment of wood fibers on the properties of the flatpressed wood plastic composite panels and found the dimensional stability of composites was improved with the increasing treatment temperature and time. Lafia-Araga et al. (2012) discovered an increase in tensile modulus in heat treated wood as compared to untreated when heat-treated wood flour was used in polyethylene (PE) composite. Aydemir et al. (2015) investigated the mechanical and rheological properties of heat treated lignocellulosic filled polymer composites and found the heat treatment substantially affected the mechanical and rheological properties of wood filled nylon 6 composites. Robin and Breton, (2001) investigated the benefit of using such heat treated wood as reinforcement for a waste plastic and found the heat treatment of wood fibers could greatly improve mechanical properties of wood fibers/PE composites. Nowadays, it is well known that thermal modification and acetylation are commercially available in wood modification processes.

Most polymers used in heat treated wood filled polymer composites are polyolefin (polyethylene (PE) and polypropylene (PP)) based materials (Table 1.). Mechanical and rheological properties of nylon 6-wood composite are investigated by Aydemir et al. (2015). It is found that thermal stability of wood fiber increased because hemicellulose degrades and lignin condenses. Heat treatment modification significantly affected on the mechanical and rheological properties of nylon 6 composites. The physical, mechanical, thermal dynamic mechanical property of wood flour/polypropylene (PP) composite was investigated by Luo et al., (2014). It is found that the surface hydroxyl group and hygroscopicity of wood flour increased with glycerin treatment alone, however, had no improvement on the impact and flexural strength. They found that the glycerin and heat treatment significantly reduced thickness swelling of the composite and strengthened the impact properties of composite, because the hydroxyl groups on the surface of wood flour reduces and interfacial bonding between wood flour and PP improves. Kaboorani, (2009) investigated the effect of using heat treated wood flour in PP composites on thermal properties of composites. He found that thermally wood has significantly positive effect on thermal stability of wood because of decomposition of hemicellulose and structural changes in cellulose and lignin. The moisture adsorption properties, biological durability, mechanical properties of thermally modified wood components and polylactate matrix is investigated by Segerholm et al (2012). All WPC samples showed low mass, strength and stiffness losses compared to unmodified WPC component that lost $35-40 \%$ of its mechanical properties. 
Styrene Maleic Anhydride (SMA) is an engineering thermoplastic that comes from copolymerization of styrene and maleic anhydride monomers. SMA normally uses as engineering plastic for the automotive industry. It can be injection molded and thermoformed to make interior components. The reason of using SMA is that it shows a similar behavior to modified polypropylene (MAPP) (Takase and Shiraishi, 1989). The other advantages of using SMA plastic in automobiles include that SMA can be recycled and ability to add materials to it to improve the strength properties in end uses. The anhydride component of SMA is used to develop the reaction and adhesion between polymer and fillers in the composite industry (Han and Gardner, 2010; Lu et al., 2005; Kishi et al., 1988; Zor et al., 2016). The mechanical properties can be improved by using glass fillers. These fillers have shortcomings with regard to environmental safety. In the meantime, the industrial manufacturing arena has paid significant attention to the use of wood as reinforcing filler for thermoplastics (Woodhams et al., 1984; Yam et al., 1990). Simonsen et al. (1998) were among the first researchers to examine the utilization of wood fillers in
SMA composites. They analyzed old newsprint and aspen and pine wood flours as fillers in SMA. They compounded the wood fillers and SMA in a high-energy kinetic mixer followed by injection molding of the compounded wood SMA material. They reported that the wood filled SMA composites were superior to unfilled SMA in strength, stiffness and notched Izod impact strength. The esterification reaction between the hydroxyl groups of wood and the anhydride groups of SMA generates water which is used a forming agent. The density of neat SMA is $1.08 \mathrm{~g} / \mathrm{cm}^{3}$ and of the foamed SMA/wood composites is $0.60 \mathrm{~g} / \mathrm{cm}^{3}$ (Han and Gardner, 2009). Aydemir et al (2015a) investigated the thermal properties of foamed nano/macro filler-reinforced styrene maleic anhydride (SMA) composites. They found that thermal degradation of all foamed composites was found to be lower than that of SMA composites. Aydemir et al (2014a) researched to investigate the foaming of SMA matrix composites with a physical foaming agent, created during the reactive extrusion of natural fibers and SMA. They found that hydroxyl number was very important effect on foaming composites.

Table 1. Heat treated wood plastic composites (Modified from Aydemir et al., 2015)

\begin{tabular}{|c|c|c|c|c|c|}
\hline Polymer & $\begin{array}{l}\text { Type of } \\
\text { wood }\end{array}$ & $\begin{array}{c}\text { Heat treatment } \\
\text { temperature } \\
\left({ }^{\circ} \mathrm{C}\right)\end{array}$ & $\begin{array}{c}\text { Processing } \\
\text { aid/surface } \\
\text { modification }\end{array}$ & Processing Method & Reference \\
\hline \multirow{8}{*}{ HDPE } & Alder & 170 & MAPE & Extrusion/Injec. Mol. & Tufan et al., 2016 \\
\hline & Bamboo & 150,180 & - & Extrusion/Injec. Mol. & Li et al., 2015 \\
\hline & Bamboo & 150,180 & - & Extrusion/Injec. Mol. & Du et al., 2014 \\
\hline & Bamboo & $\begin{array}{l}160,175, \\
190,205,220\end{array}$ & MAPP & $\begin{array}{l}\text { Extrusion,Compressio } \\
\mathrm{n}, \text { Mol. }\end{array}$ & Fang et al., 2013 \\
\hline & Maple & $175,190,205$ & MAPP & Extrusion/Injec. Mol. & $\begin{array}{l}\text { Kaboorani and } \\
\text { Faezipour, 2009 }\end{array}$ \\
\hline & Red Balau & 180,200 & - & Extrusion/Injec.Mol. & $\begin{array}{l}\text { Lafia-Araga et al., } \\
2012\end{array}$ \\
\hline & Maple & $175,190,205$ & MAPP & Extrusion/Injec. Mol. & Kaboorani et al., 2008 \\
\hline & $\begin{array}{l}\text { Spruce and } \\
\text { Natural } \\
\text { Fibers }\end{array}$ & 230 & - & $\begin{array}{l}\text { Industrial Mill /Injec. } \\
\text { Mol. }\end{array}$ & $\begin{array}{l}\text { Robin and Breton, } \\
2001\end{array}$ \\
\hline \multirow{6}{*}{ PP } & Poplar & 140 & $\begin{array}{l}\text { Polyethylene } \\
\text { Glycol Imp. }\end{array}$ & $\begin{array}{l}\text { High speed Mixer/Hot } \\
\text { Press }\end{array}$ & Luo et al., 2013 \\
\hline & $\begin{array}{l}\text { Norway } \\
\text { Spruce }\end{array}$ & 212 & - & Extrusion/Injec. Mol. & Segerholm, 2007 \\
\hline & $\begin{array}{l}\text { Birch and } \\
\text { Spruce }\end{array}$ & 180 & MAPP & Extrusion & Butylina et al., 2011. \\
\hline & Poplar & 200 & MAPP & HBI mixing system & Kaboorani, 2009. \\
\hline & Poplar & 200 & Glycerin & Extrusion, Hot press & Luo et al, 2014. \\
\hline & Eucalyptus & $120,150,180$ & - & $\begin{array}{l}\text { Rotary Drum Blender/ } \\
\text { Hot Press }\end{array}$ & Ayrilmis, et al, 2011 \\
\hline
\end{tabular}


Table 1 (continued)

\begin{tabular}{clccll}
\hline & Flax & 160 & MAPP & Non-woven Mat & $\begin{array}{l}\text { Stamboulis et al., } \\
2000\end{array}$ \\
\hline \multirow{2}{*}{ CAB } & $\begin{array}{l}\text { Norway and } \\
\text { Spruce }\end{array}$ & 212 & - & Extrusion/Injec. Mol. & Segerholm, 2007 \\
\hline \multirow{2}{*}{ PLA } & $\begin{array}{l}\text { Norway and } \\
\text { Spruce }\end{array}$ & 212 & - & Extrusion/Injec. Mol. & Segerholm et al., 2012 \\
\hline \multirow{2}{*}{ Nylon-6 } & $\begin{array}{l}\text { Pine and } \\
\text { Maple }\end{array}$ & 212 & - & Extrusion/Injec. Mol. & Aydemir et al., 2015 \\
\hline
\end{tabular}

In spite of the academic and industrial interest in heat treated wood, only few studies of heat treated lignocellulosic filled polymer composites have been published in the literature. In this study, the effect of heat treated wood fillers on physical, mechanical and morphological properties of SMA at different filler loading levels was investigated. The objective of this paper is also to establish and optimize a production process for engineering thermoplastic composites based on heat treated wood fillers and SMA copolymer.

\section{Material and Method Materials}

The SMA (XIRAN® ${ }^{\circledR}$ SE700) was supplied by Poyscope Polymer, USA. It has a density of $1.08 \mathrm{~g} / \mathrm{cm}^{3}$ (Maleic anhydride contents $10 \%$ wt., melt flow $22 \mathrm{~g} / 10 \mathrm{~min}$ at $\left.240^{\circ} \mathrm{C} / 10.0 \mathrm{~kg}\right)$. The eastern white pine (Pinus strobus L.), used as fillers in this study, was kindly supplied by Wicks Lumber in Pittsfield, ME, USA.

\section{Heat treatment}

Pine wood samples were cut from the sapwood of a radial board of eastern white pine (Pinus strobus L.). Cubic samples with $360 \mathrm{~mm} \times 20 \mathrm{~mm} \times 20 \mathrm{~mm}$ were cut with clear faces, kept in a conditioned room at $20^{\circ} \mathrm{C}$ and $50 \%$ relative humidity for 3 weeks and weighed afterwards. The heat treatment was made in an oven heated by electric coils located in the walls and with exhaustion of the heated gases by natural convection through an opening in the oven wall. The treatment last for $8 \mathrm{~h}$ and at $212^{\circ} \mathrm{C}$. The treatment started by putting the samples at ambient temperature in the oven. The time to reach the treatment temperature was about 60 min. After heat treatment, the solid wood board samples were removed from the oven and ground in a grinder. Wood flour of pine greater than 60 mesh was used as raw materials to prepare the wood flour/SMA copolymer composites. Untreated samples were used as the control.

\section{Processing of composite materials}

The wood flour retained on 60-mesh size sieve was dried to a moisture content of less than $1 \%$ using a conventional oven at $105^{\circ} \mathrm{C}$ for $16 \mathrm{~h}$. This mixture was compounded in a twin-screw extruder (C. W. Brabender $20 \mathrm{~m}$ Clamshell Segmented). The temperature profiles for extruder were $210^{\circ} \mathrm{C}, 220^{\circ} \mathrm{C}$, $220^{\circ} \mathrm{C}, 220^{\circ} \mathrm{C}, 220^{\circ} \mathrm{C}, 210^{\circ} \mathrm{C}$ and rotor speed at $60 \mathrm{rpm}$. The SMA-wood flour compounds were granulated using a lab-scale grinder. The ground particles were dried in an oven at $105{ }^{\circ} \mathrm{C}$ for $16 \mathrm{~h}$ before being injection molded into ASTM test specimens. All materials were injection molded using a barrel temperature of $230^{\circ} \mathrm{C}$ mold temperature of $220^{\circ} \mathrm{C}$ injection pressure of $17 \mathrm{MPa}$. The compositions of the composites are shown in Table 2.

Table 2. Composition of SMA, untreated and heat treated composites

\begin{tabular}{ccc}
\hline $\begin{array}{c}\text { SMA } \\
(\boldsymbol{\%})\end{array}$ & $\begin{array}{c}\text { Untreated } \\
\text { wood } \\
(\boldsymbol{\%})\end{array}$ & $\begin{array}{c}\text { Heat- } \\
\text { treated wood } \\
(\boldsymbol{\%})\end{array}$ \\
\hline 100 & - & - \\
90 & 10 & - \\
80 & 20 & - \\
70 & 30 & - \\
60 & 40 & - \\
50 & 50 & - \\
90 & - & 10 \\
80 & - & 20 \\
70 & - & 30 \\
60 & - & 40 \\
50 & - & 50 \\
\hline
\end{tabular}




\section{Characterization}

\section{Physical Testing}

Water absorption and thickness swelling tests were conducted in accordance with ASTM D570-98, in which the specimens were immersed in water for $2 \mathrm{~h}, 24 \mathrm{~h}$ and 48 hours at a temperature $23 \pm 1^{\circ} \mathrm{C}$. The moisture content of the composite materials calculated based on the following equation (1):

$$
M C(\%)=\frac{(\mathrm{m} 1-\mathrm{m} 0)}{\mathrm{m} 0} \times 10
$$

where $\mathrm{m} 0$ and $\mathrm{m} 1$ are the oven-dry mass and the mass before the immersion test, respectively. In addition, thickness of each specimen was also measured for determination of the thickness swelling (TS) by using the following equation (2):

$$
\operatorname{TS}(\%)=\frac{(\mathrm{\gamma} 1-\mathrm{\gamma} 0)}{\mathrm{y} 0} \times 100
$$

in which $\mathrm{\gamma} 1$ and $\mathrm{\gamma} 0$ are the panel thickness after and before the water immersion, respectively. Water absorption values were plotted versus root time/thickness values. Then, the slope of the linear portion of the curves (m) was determined. Water diffusion coefficient of the composite formulation was calculated by using following Eq. 3 (Shen and Springer, 1976). This formula has been widely used for natural fiber (wood flour) plastic composites (Najafi et al., 2007a; Najafi et al., 2007b; Najafi et al., 2008; Espert et al., 2004; Tajvidi et al., 2006; Tajvidi et al., 2008) and has been found to work well.

$$
D=\pi\left[\frac{m h}{4 M_{\infty}}\right]^{2}\left[1+\left(\frac{h}{L}\right)+\left(\frac{h}{n}\right)\right]^{2}
$$

where $D$ is the water diffusion coefficient corrected for edge effect; $m$, the gradient of linear portion of the water content against root time/thickness curve; $M_{\infty}$, the equilibrium moisture content, which is the valueof the water absorbed such that there is no furtherchange in the water absorption with time; $h$, the thick-ness; $L$, the length; and $n$ is the width.

A new thickness swelling model of wood based composite identification of thickness swelling process was improved by (Shi and
Gardner, 2006). In this model, swelling rate parameter $\left(\mathrm{K}_{\mathrm{SR}}\right)$ obtained from the test data are used to quantify thickness swelling rate.

The swelling model can be emphasized as follows:

$$
T S(t)=\left(\frac{T_{\infty}}{T_{0}+\left(T_{\infty}-T_{0}\right) e^{-K} S R^{t}}-1\right) * 100
$$

where $T_{\infty} \infty$ and $T_{0}$ are the equilibrium and initial specimen thicknesses, respectively. Constant of $\mathrm{K}_{\mathrm{SR}}$ is the initial (or intrinsic) relative swelling rate and $\mathrm{TS}(\mathrm{t})$ is swelling at any given time (t). Rearranging Eq. 4 gives:

$\frac{100 T_{\infty}}{T S(t)+100}-T_{0}=\left(T_{\infty}-T_{0}\right) e^{-K_{S R} t}$

taking natural logarithm of both sides of Eq. 5 yields:

$\ln \left(\frac{100 T_{\infty}}{T S(t)+100}-T_{0}\right)=\ln \left(T_{\infty}-T_{0}\right)-K_{S R^{t}}(6)$

which would give a straight line with the slope of $-K_{S R}$ on a linear scale from which the swelling rate can be calculated. For quantifying the swelling rate, a swelling rate parameter $\left(\mathrm{K}_{\mathrm{SR}}\right)$ was used. Density of the composite was determined based on the oven-dry weight and the volume.

\section{Mechanical Testing}

The flexural modulus of rupture (MOR) and modulus of elasticity (MOE) were determined with a three-point bending test using Instron 8801 with a $4.48 \mathrm{~N}$ load cell (ASTM 790-03). The support span was 50 $\mathrm{mm}$, resulting in a span-to-depth ratio of 16 $( \pm 1)$ and tests were run at a test speed of 1.27 $\mathrm{mm} / \mathrm{min}$. Displacement of tests specimen measured using crosshead movement data from the Instron machine. Tensile tests were performed according to ASTM 638-03. The specimens were tested with crosshead speed of $5.08 \mathrm{~mm} / \mathrm{min}$. An extensometer was employed to determine elongation of the samples. Seven samples for each composition WPC group were used in flexural test and tensile test, and the results are presented as an average for tested samples. 


\section{Scanning Electron Microscopy (SEM)}

The morphological properties of composites were characterized out using a Hitachi-TM 3000 table-top microscope at an acceleration voltage of $15 \mathrm{kV}$. The flexural specimens were first dipped in liquid nitrogen and snapped in half.

\section{Results and Discussions Physical Properties}

Figures 1 and 2 show the short-term values of the water absorption (WA) and thickness swelling (TS) for the heat treated wood flour/SMA copolymer composites. According to results, the water absorption and thickness swelling increased with the wood flour content. These results are similar to those reported by Kord (2012) and Bhaskar et al., (2012). There are two known factors affecting water absorption of wood flour-filled composite materials. The first one is the intrinsic hydrophilic nature of the wood flour and its ability to retain water molecules due to numerous accessible hydroxyl groups in wood flour. This effect increases the water absorption of the composites as a function of the wood content. Voids and gaps, which are generated during the composite manufacturing process, can also affect water absorption of the composite materials, because they can give a preferential path to the infiltrated water (rull et al., 2014). It can be seen in Figure 1 and 2 that the composites containing 50 wt. \% untreated wood flour displayed the highest TS and WA of all the samples, $\mathrm{TS}_{\max }$ (3.91\%) and $\mathrm{WA}_{\max }(6.06 \%)$ more than the control samples, respectively. In general, the WA and TS of SMA/wood composites produced with heat treated pine (TP) was less than that of produced with untreated pine. The reduction in WA and TS in SMA copolymer composites produced with heattreated fillers can be explained by the removal of large parts of hygroscopic hemicelluloses with their accessible $\mathrm{OH}$ groups during heat treatment process (Skaar 1972 and Rowel 2007). Higher concentration of lignin in the wood flour after heat treatment process may be another reason for the reduction in both the hydroxyl groups and hygroscopicity of the wood flour (Hosseinaei et al., 2012). Similar results were also reported by other researchers for hot water extracted wood filled PP and HDPE composites, hemicellulose extracted wood filled PP and heat treated alder wood filled HDPE composites, respectively (Pelaez-Samaniego et al., 2013 and Tufan et al., 2016). Du et al., (2014) also found that water absorption values increased with increasing bamboo fibers (BFs) loading content and obtained less water absorption values in heat treated BFs/HDPE composite in comparison of the untreated BFs/HDPE composites. Thickness swelling behavior of wood flour/SMA composites including 50P was highest, and in composites containing $10 \mathrm{TP}$ showed the lowest value.

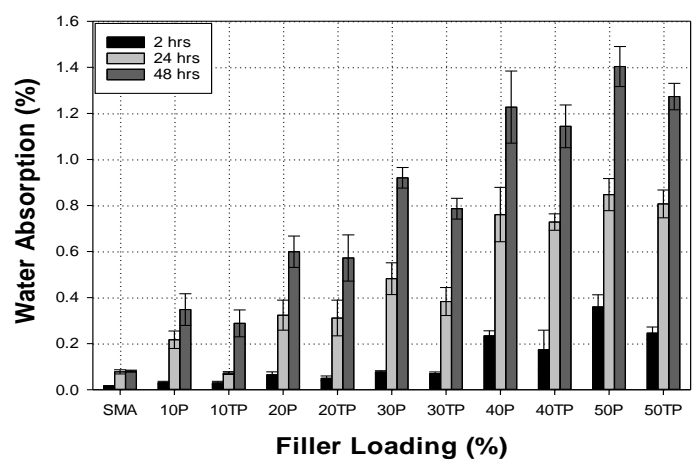

Figure 1. Water absorption of heat treated SMA/wood composites (P:untreated pine wood; TP: heat treated pine wood)

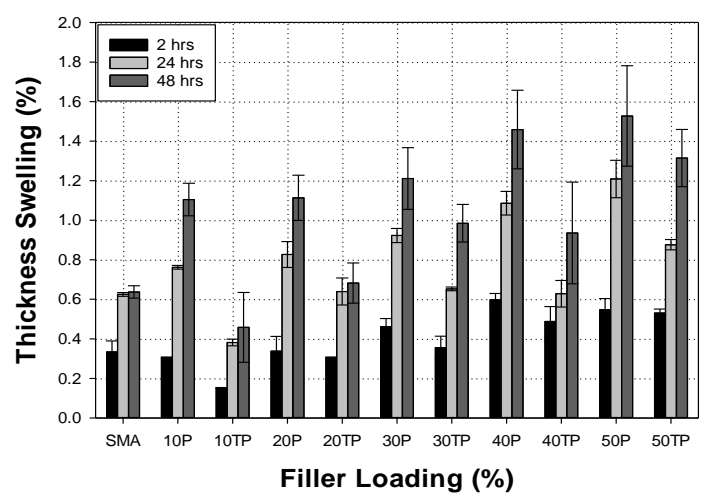

Figure 2. Thickness swelling of heat treated SMA/wood composites. (P: untreated pine wood; TP: heat treated pine wood)

Water diffusion coefficients were calculated using Eq.3. As shown in Figure 3, $\mathrm{m}$ and $\mathrm{D}$ values presented a similar trend as affected by wood flour content, a significant increase with increasing with the wood flour loading content in the composites. All of 
these described that adding wood flours to the composites led to increased diffusion rate of water in the wood flour-filled/SMA composites as a result of wood flours being a hygroscopic material. As show in Figure 4, swelling rate constant of the wood flour/SMA composites were clearly dependent upon both heat treated and untreated wood flour filler content too.

Natural fiber composites have three major mechanisms of moisture absorption. The first is diffusion of water molecules inside the micro gaps between polymer chains; second is the capillary transport of water molecules into the gaps and flaws at the interface between fibers and the polymer due to the incomplete permeation of water; finally the third mechanism is the transport of water molecules by micro cracks in the matrix, that are formed during the compounding process (Dhakal et al., 2007; Espert et al., 2004; Ahmad et al., 2010).

Figure 5 shows the density of neat SMA and wood flour filled composites. The neat SMA $\left(1.08 \mathrm{~g} / \mathrm{cm}^{3}\right)$ was less dense compared to the wood flour filled SMA composites. With increasing wood flour contents, the density of composite increased due to higher density of wood flour compare to the SMA polymer matrix and also the lower content of polymer matrix which is foamable. Similar result was also obtained and reported by Matuana, et al., (1998).

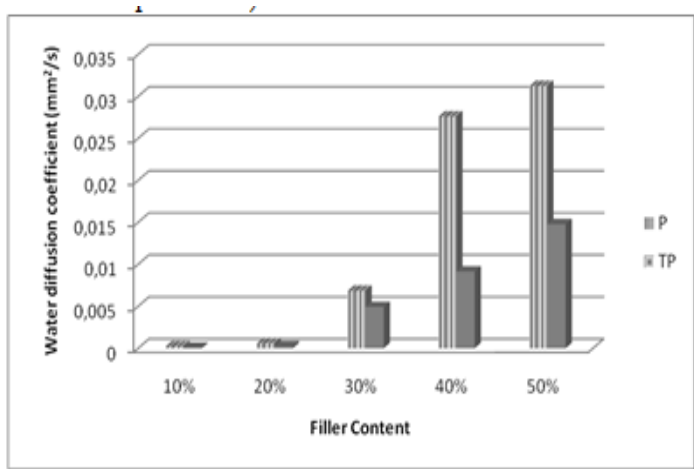

Figure 3. The effect of loading filler contents on water diffusion coefficients (P: untreated pine wood, TP: heat treated pine wood)

\section{Mechanical Properties}

Flexural properties of the SMA matrix composites were given in Figs. 6, and 7 . Flexural strength and flexural modulus of elasticity of heat treated wood flour/SMA composites increased with the addition of wood fiber. $50 \% \mathrm{P}$ exhibited the lowest flexural strength $(68.10 \mathrm{MPa})$, and the highest flexural strength was from $50 \% \mathrm{TP}$ $(75.31 \mathrm{MPa})$. The test results showed that wood flour has a positive effect on the properties of SMA (Figure 6). Figure 7 shows that flexural modulus of elasticity (FMOE) of neat SMA and wood flour/SMA composites. FMOE of neat SMA was 1.96 GPa. The FMOE of wood flour filled composites increased linearly with wood flour loading. Wood fillers enhanced the FMOE of the wood flour/SMA composites. Simonsen et al., (1998) studied compounding SMA with newspaper, wood flour and aspen fiber. The results showed that $\mathrm{MOE}$ increased with the addition of 10 to $20 \mathrm{wt}$. \% wood flour. Figure 8 shows that $30 \mathrm{wt} \%$ heat treated wood filled SMA composites had higher tensile strength among all formulations with $11.87 \%$ increase in tensile strength compared to neat SMA (Table 3).

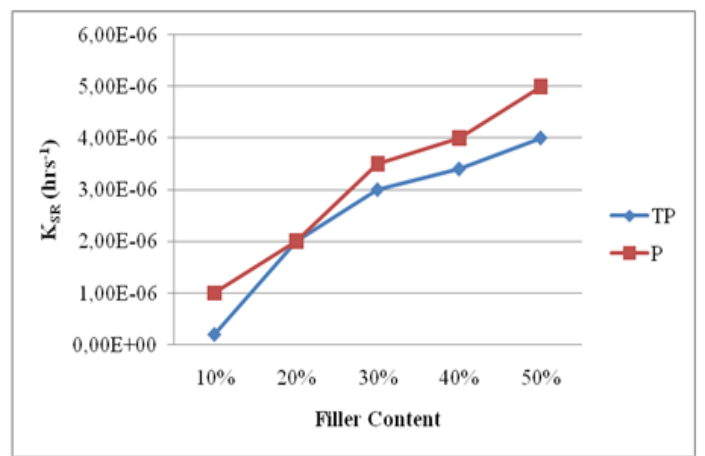

Figure 4. The effect of loading filler contents on swelling rate constant (P: untreated pine wood, TP: heat treated pine wood)

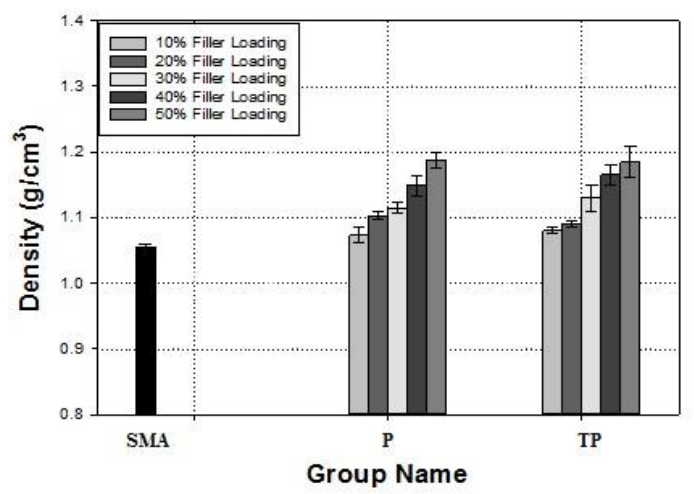

Figure 5. Densities as function of wood flour loading for natural fibers/SMA composites 


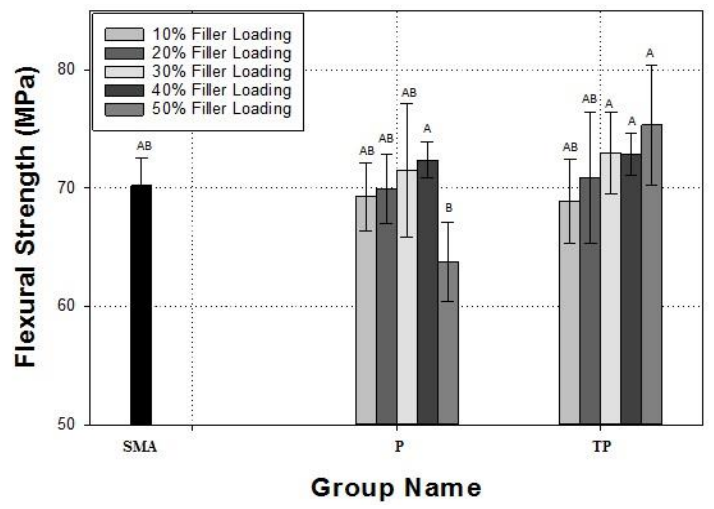

Figure 6. Flexural strength of heat treated and untreated wood flour/SMA composites

Table 3. Summary of mechanical properties of wood filler/SMA composites

\begin{tabular}{|c|c|c|c|c|c|c|c|c|c|c|c|}
\hline Properties & SMA & $10 \% \mathrm{P}$ & $10 \% \mathrm{TP}$ & $20 \% \mathrm{P}$ & $20 \% \mathrm{TP}$ & $30 \% \mathrm{P}$ & $30 \% \mathrm{TP}$ & $40 \% \mathrm{P}$ & $40 \% \mathrm{TP}$ & $50 \% \mathrm{P}$ & $50 \% \mathrm{TP}$ \\
\hline $\begin{array}{c}\text { Flexural } \\
\text { Stress }\end{array}$ & $\mathrm{AB}$ & $\begin{array}{c}\mathrm{AB} \\
(\mathrm{NC})\end{array}$ & $\begin{array}{l}\mathrm{AB} \\
(\mathrm{NC})\end{array}$ & $\begin{array}{l}\mathrm{AB} \\
\text { (NC) }\end{array}$ & $\begin{array}{c}\mathrm{AB} \\
(\mathrm{NC})\end{array}$ & $\begin{array}{c}\mathrm{AB} \\
(\mathrm{NC})\end{array}$ & $\begin{array}{c}\mathrm{A} \\
(3.9 \%)\end{array}$ & $\begin{array}{c}\mathrm{A} \\
(3.1 \%)\end{array}$ & $\begin{array}{c}\mathrm{A} \\
(3.8 \%)\end{array}$ & $\begin{array}{c}\mathrm{B} \\
(-9.2 \%)\end{array}$ & $\begin{array}{c}\mathrm{A} \\
(7.3 \%)\end{array}$ \\
\hline & $\mathrm{F}$ & $\mathrm{EF}$ & $\mathrm{E}$ & $\mathrm{E}$ & & $\mathrm{CD}$ & $\begin{array}{c}\mathrm{C} \\
(94.4 \%)\end{array}$ & $\mathrm{B}$ & $\begin{array}{c}\mathrm{B} \\
(131.6 \%)\end{array}$ & $\begin{array}{c}\mathrm{B} \\
(137.2 \%)\end{array}$ & $\begin{array}{c}\mathrm{A} \\
(171.4 \%)\end{array}$ \\
\hline $\begin{array}{l}\text { Tensile } \\
\text { Stress }\end{array}$ & $\mathrm{BC}$ & $\begin{array}{c}\mathrm{BC} \\
\text { (NC) }\end{array}$ & $\begin{array}{c}\mathrm{C} \\
(-1.6 \%)\end{array}$ & $\begin{array}{c}\mathrm{ABC} \\
(3.4 \%)\end{array}$ & $\begin{array}{c}\mathrm{ABC} \\
(4.5 \%)\end{array}$ & $\begin{array}{c}\mathrm{AB} \\
(7.6 \%)\end{array}$ & $\begin{array}{c}\mathrm{A} \\
(11.9 \%)\end{array}$ & $\begin{array}{c}\mathrm{ABC} \\
(7.1 \%)\end{array}$ & $\begin{array}{c}\mathrm{A} \\
(2.9 \%)\end{array}$ & $\begin{array}{c}\mathrm{BC} \\
\text { (NC) }\end{array}$ & $\begin{array}{c}\mathrm{BC} \\
\text { (NC) }\end{array}$ \\
\hline $\begin{array}{c}\text { Tensile } \\
\text { Modulus } \\
\end{array}$ & G & $\begin{array}{c}\text { FG } \\
(22.9 \%)\end{array}$ & $\begin{array}{c}\text { FG } \\
26.6 \%) \\
\end{array}$ & $\begin{array}{c}\mathrm{EF} \\
(47.1 \%) \\
\end{array}$ & $\begin{array}{c}\mathrm{F} \\
45.7 \%) \\
\end{array}$ & $\begin{array}{c}\mathrm{DE} \\
(73.4 \%) \\
\end{array}$ & $\begin{array}{c}\mathrm{CD} \\
(97.4 \%)\end{array}$ & $\begin{array}{c}\mathrm{BC} \\
(101.4 \%) \\
\end{array}$ & $\begin{array}{c}\mathrm{B} \\
118.1 \%) \\
\end{array}$ & $\begin{array}{l}\text { A } \\
67.6 \%)\end{array}$ & $\begin{array}{c}\mathrm{A} \\
74.4 \%) \\
\end{array}$ \\
\hline
\end{tabular}

The same letters indicate no statistical difference between properties of composites and those around it. $\mathrm{NC}$ is no significant change on the addition of wood flour loading $(\alpha=0.05)$, and parenthesis show the effect of wood flour loading on the mechanical properties of composites in comparison with the neat SMA.

Figure 9 shows the tensile modulus of elasticity (TMOE) of neat SMA and wood flour/SMA composites. TMOE of neat SMA was $2.93 \mathrm{GPa}$. The TMOE of wood flour filled composites increased with increasing wood flour loading level. The 50 wt. \% heat treated pine wood filled/SMA composites had higher TMOE among the all formulations with $174.40 \%$ increase in TMOE compared to neat SMA copolymer. The tensile strength of composites increases with wood content in composite materials. Similar results were also obtained and reported by other authors Wolcott, (2003) and Bengtsson, et al., (2007). Heat treatment degrades hemicelluloses and reduces the polymerization degree. These effects could decrease the flexural/tension strength of WPCs, as previously reported by Mohebby et al., (2008); Ayrilmis et al., (2011); Tufan, et al., (2016).

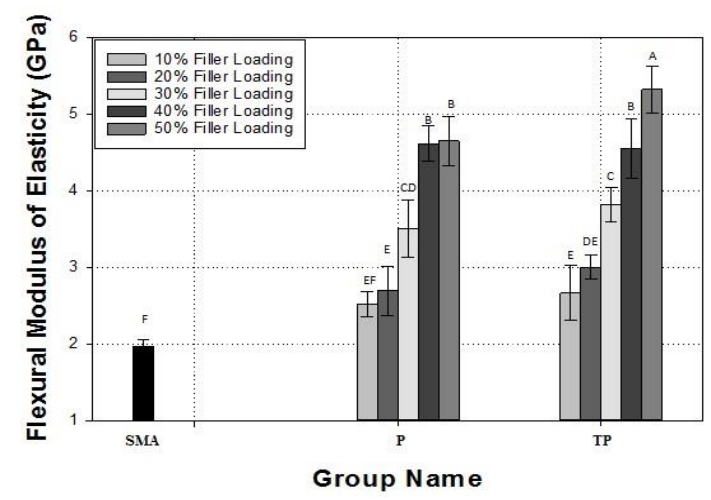

Figure 7. Flexural modulus of elasticity of heat treated and untreated wood flour/SMA composites

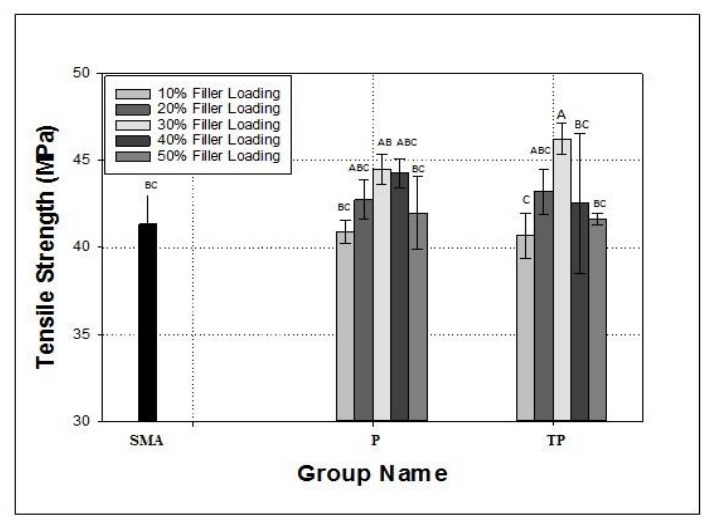

Figure 8. Tensile strength of heat treated and untreated wood flour/SMA composites 


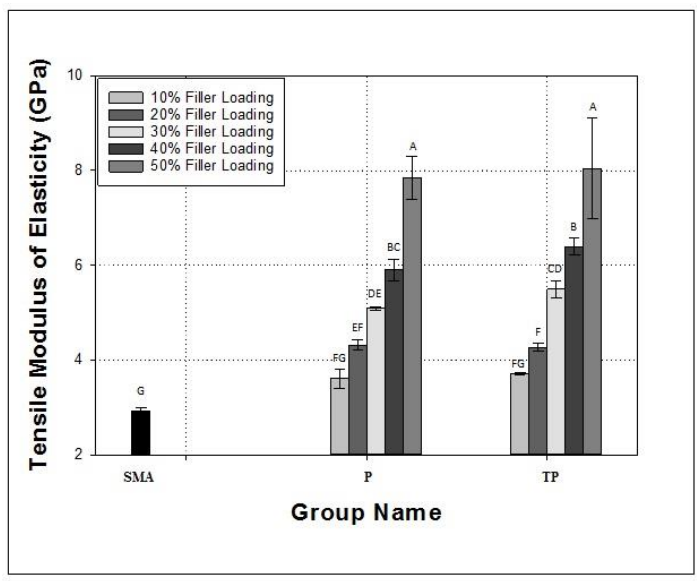

Figure 9. Tensile modulus of elasticity of heat treated and untreated wood flour/SMA composites

\section{Morphological Properties}

The morphology of the composites was investigated by SEM. The images were used to compare interfacial bonding between natural fibers and SMA. SEM images also pointed out a few weak interface spots where crack propagation occurred. The weak interface between fiber (wood flour) and matrix (SMA) can be observed in neat SMA, $20 \% \mathrm{P}, 20 \% \mathrm{TP}, 40 \% \mathrm{P}$ and $40 \% \mathrm{TP}$ in Figure 9. It was observed that the heat treated wood flour/SMA composite exhibited better adhesion between the wood fillers and the polymer matrix in comparison to the untreated wood flour filled/SMA composites. There were some cracks and voids between wood flour and matrix in the untreated wood flour/SMA composites. The heat treated wood flour/SMA composites showed a more homogeneous fracture surface with less cracks and gaps. Similar results were also reported by Tufan et. al., (2016).

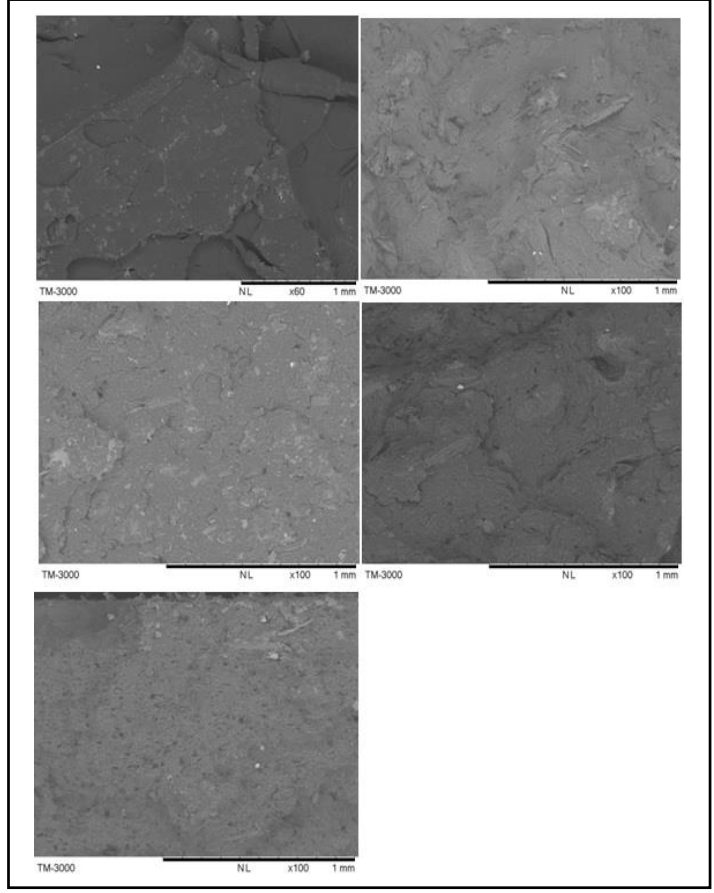

Figure 10. SEM images (x100) of fractured surface of neat SMA, $20 \% \mathrm{P}, 20 \% \mathrm{TP}, 40 \% \mathrm{P}$ and $40 \% \mathrm{TP}$

\section{Conclusions}

Heat treated wood fillers reinforced SMA composites were produced by melt compounding. The following conclusions could be drawn from the results of the present study:

$\checkmark$ The water absorption and thickness swelling increased with the heat treated wood flour content.

$\checkmark$ Compared to the control samples, 30 wt. \% wood flour/SMA composites produced with heat treated wood showed a significantly higher tensile strength.

$\checkmark$ Heat treated wood flour/SMA composites with 40 wt. $\%$ and 50 wt. $\%$ filler addition show agglomeration and degradation, thus strength decreased..

$\checkmark$ Wood fillers have a positive effect on FMOE and TMOE of the heat treated wood flour/SMA composites.

$\checkmark$ Weak interfacial bonding was observed between the polymer and the wood filler from the SEM images of the fractured surfaces of wood flour/SMA composites. 
$\checkmark \quad$ It is possible to produce composites of wood flour filled SMA with melt compounding followed by injection molding. The composites reinforced with heat treated and untreated wood flour displayed enhanced tensile and flexural properties in comparison to the neat SMA. SMA with 30 wt. \% of wood flour shows comparable or higher mechanical properties than other filler loading levels.

\section{References}

Ahmad, S.H., Rasid, R., Bonnia, N.N., Zainol, I., Mamun A.A., Bledzki, A.K., and Beg, M.D.H. (2010). Polyester-kenaf composites: effects of alkali fiber treatment and toughening of matrix using liquid natural rubber. Journal of Composites Materials, 45(2), 203-217.

Aydemir, D., Kiziltas, A., Gardner, D. J., Han, Y., Gunduz, G. (2014a). Morphological characterization of foamed natural filler-reinforced styrene maleic anhydride (SMA) composites. Journal Porous Mater., 21, 1059-1067.

Aydemir, D., Kiziltas, A., Gardner, D. J., Han, Y., Gunduz, G. (2015a). Thermal analysis of micro- and nano lignocellulosic reinforced styrene Maleic anhydride composite foams. International Journal of Polymer Anal. And Charact., 20, 231-239.

Aydemir, D., Kiziltas, Al., Kiziltas, E. E., Gardner, D.J., Gunduz, G. (2015). Heat treated wood-nylon 6 composites. Composites: Part B, 68(2), 414-423.

Ayrilmis, N., Jarusombuti, S., Fueangvivat, V., and Bauchongkol, P. (2011). Effect of thermal-treament of wood fibers on properties of flat-pressed wood plastic composites. Polymer Degredation and Stability, 96, 818-822.

Bengtsson, M., Baillif, M. Le, Oksman, K.(2007). Composites Part A, 38, 1922.

Bhaskar, J., Haq, S., Pandey, A. K., Srivastava, N. (2012). Evaluation of properties of propylene-pine wood plastic composite, J. Mater. Emviron. Sci. 3(3), 605-612.

Butylina S, Martikka O, Karki T. (2011). Properties of wood fibre-polypropylene composites: effect of wood fibre source. Appl Compos Mater, 18(2), 101-11.

Dhakal, H.N., Zhang, Z.Y. and. Richardson, M. O. W. (2007). Effect of water absorption on the mechanical properties of hemp fiber reinforced unsaturated polyester composites. Composites Science and Technology, Vol. 6-19.

Du, L., Li, Yç, Lee, S., and Wu, Q. (2014). Water absorption bamboo composite. Bioresources, 9(1), 1189-1200.

Espert, A., Vilaplana, F. and Karlsson, S. (2004). Comparison of water absorption in natural cellulosic fibers from wood and one year crops in polypropylene composites and its influence on their mechanical. Composites Part: A, 35, 1267-1276, 2004.

Espert, A.., Vilaplana, F., Karlsson, S. (2004). Comparison of water absorption in natural cellulosic fibres from wood and one-year crops in polypropylene composites and its influence on their mechanical properties. Composites Part A: Applied Science and Manufacturing 35, 1267-1276.

Esteves, B., and Pereira, H. M., (2009). Wood modification by heat treatment: A review, Bioresources, 4(1), 370-404.

Fang, H., Wu, Q, Hu, Y., Wang, Y., Yan, X. (2013). Effects of thermal treatment on durability of short bamboo-fibers and its reinforced composites. Fibers Polym, 14(3), 436-40.

Groot, D., W.F., W.P. Pan, M.D. Rahman and G.N. Richards. (1988). First chemical events in pyrolysis wood. J. Anal. Appl. Pyrolysis, 13, 221-231.

Han, Y., Gardner, D. (2010). Foamed styrene-based WPC using physical blowing agent created during reactive extrusion, 10th International Conference on Wood and Biofiber Plastic Composites and Cellulose Nanocomposites Symposium, Madison, WI, May 11-13.

Han, Y., Gardner, D.J. (2009). Foamed Styrene-Based WPC using Physical Blowing Agent Created during Reactive Extrusion. In: Proceedings, 10th International Conference on Wood fiberPlastic Composites, May; Madison, Wisconsin, USA. Forest Products Society. 
Hill, C. A. S. (2006). Wood Modification: Chemical, Thermal and Other Processes. John Wiley \& Sons Ltd. West Susses, England.

Hosseinaei, O., Wang, S., Enayati A.A. and Rials T.G. (2012). Effects of hemicellulose extraction on properties of wood flour and wood-plastic composites. Composites Part A: Applied Science and Manufacturing, 43(4), 686-694.

Kaboorani, A., Faezipour M, Ebrahimi G. (2008). Feasibility of using heat treated wood in wood/thermoplastic composites. J Reinf Plast Compos, 27(16-17), 16891699.

Kaboorani, A., Faezipour M.(2009). Effects of wood preheat treatment on thermal stability of HDPE composites. J Reinf Plast Compos., 28(24), 2945-55.

Kaboorani, A. (2009). Thermal properties of composites made of heat-treated wood and polypropylene. J Compos Mater, 43(22), 2599-607.

Kamdem, D.P., Pizzi, A. and Jermannaud, A. (2002). Durability of heat-treated wood. Holz als Rohund Werkstoff, 60,1-6.

Kishi, H,. Yoshioka, M., Yamanoi, A., Shiraishi, N. (1988). Composites of wood and polypropylenes. I. Mokuzai Gakkaishi, 43(2), 133-139.

Kord, B. (2012). The impact of plastics virginity on water absorption and thickness swelling of wood plastic composites. World Applied Sciences Journal, 2012, 17(2), 168-171.

Lafia-Araga, R.A., Hassan, A., Yahya, R., Rahman,N.A., Hornsby, P.R., and Heidarian, J. (2012). Thermal and mechanical properties of treated and untreated Red Balau (Shorea Dipterocarpaceae)/LDPE composites. J. Reinf. Plast. Comp. 31, 215.

Lu, J.Z., Negulescu, I.L., Wu, Q. (2005). Maleated wood-fiber=high density polyethylene composites: coupling mechanisms and interfacial characterization. Compos. Interf., 12(1), 125-140.

Luo, S., Cao, J., Peng, Y. (2014). Properties of glycerin-thermally modified wood flour/polypropylene composites. Polymer Composites, 35(2), 201-207. http://dx.doi.org/10.1002/pc.22651
Luo, S., Cao, J., Wang, X. (2013). Investigation of the interfacial compatibility of PEG and thermally modified wood flour/polypropylene composites using the stress relaxation approach. Bioresources, 8(2), 2064-73.

Marcos, M.G., and Hale M.D.C. (2009). The effect of chemical changes on the woodmoisture relationships in thermally modified wood, IRG/WP09-40473.

Matuana, L.M., Park, C.B., Balatinecz, J.J. (1998). Cell morphology and property relationships of microcellular foamed pvc/wood-fiber composites, Polymer Engineering \& Science, 38, 1862-1872.

Mohebby, B., Ilbeighi, F., and Najafi, S. K. (2008). Influence of hydrothermal modification of fibers on some physical and mechanical properties of medium density fiberboard (MDF). Holz Roh-Und Werkstoff, 66(3), 213-218.

Najafi, S.K., Kiaefar, A., Hamidina, E.,Tajvidi, M. (2007a). Water absorption behavior of composites from sawdust and recycled plastics. J Reinf Plastics Compos 26(3), 341-348.

Najafi, S.K., Kiaefar, A., Tajvidi, M. (2008). Effect of Bark Flour Content on Hygroscopic Characteristics of WoodPolypropylene. J Appl Polym Sci, 110(5), 3116-3120.

Najafi, S.K., Tajvidi, M., Hamidina, E. (2007b). Effect of temperature, plastic type and virginity on the water uptake of sawdust/plastic composites. Holz Als RohUnd Werkstoff, 65(5), 377-382.

Nebesarova, I. (1996). Etude d'un procédé de traitement pour l'association boispolymère. Ph.D, EMSE, France.

Pelaez-Samaniego, M.P., Yadama, V., Lowell, E., Amidon, T.E., Chaffee, T.L. (2013). Hot water extracted wood fiber for production of wood plastic composites (WPCs). Holzforschung, 67 (2), 193-200.

Robin, J.J. and Breton, Y. (2001). Reinforcement of recycled polyethylene with wood fibers heat treated. Journal of Reinforced Plastics and Composites, 20(14), 1253-1262.

Ross, Robert J. (2010). Wood handbook: wood as an engineering material. Centennial ed. General technical report FPL ; GTR-190. Madison, WI : U.S. 
Dept. of Agriculture, Forest Service, Forest Products Laboratory.

Rowel, R.M. (2007). Chemical modification of wood. In: Handbook of Engineering Biopolymers Homopolymers, Blends and Composites. Eds. Fakirov, S., Bhattacharyya, D. Carl Hanser Verlag, Munich. pp. 673-691.

Rull, N., Ollier, R.P., Francucci, G., Rodriguez, E.S. and Alvarez, V.A. (2014). Effect of the addition of nanoclays on the water absorption and mechanical properties of glass fiber/up resin composites. Journal of Composite Materials. 49(13), 1629-1637.

Segerholm, B.K, Ibach R.E, Westin M. (2012). Moisture sorption, biological durability, and mechanical performance of WPC containing modified wood and polylactates. Bioresources, 7(4), 45754585.

Segerholm, K. (2007). Wood plastic composites made from modified woodaspects on moisture sorption, micromorphology and durability. Licentiate Thesis, KTH, Royal Institute of Technology, Stockholm, Sweden.

Shen, C.H. and Springer, G. S. (1976). J. Composite Materials, 10, 2-20.

Shi, S.Q., Gardner, D.J. (2006). Hygroscopic thickness swelling rate of compression molded wood fiberboard and wood fiber/polymer composites. Compos A Appl Sci Manuf, 37(9), 1276-1285.

Simonsen, J., Jacobsen, R., and Rowell, R. (1998). Properties of styrene-maleic anhydride copolymers containing woodbased fillers. Forest Prod. J., 48, 89-92.

Skaar, C. (1972). Water in Wood. 1st edition. Syracuse University Press, Syracuse, NY.

Stamboulis, A., Baillie, C.A., Garkhail, S.K., Van Melick, H.G.H., Peijs, T. (2000). Environmental durability of flax fibres and their composites based on polypropylene matrix. Appl Compos Mater, 7(5-6), 273-94.

Tajvidi, M., Haghdan, S., Najafi, S.K. (2008). Physical Properties of Novel Layered Composites of Wood Flour and PVC. J Reinf Plastics Compos 27(16-17), 1759-1765.

Tajvidi, M., Najafi, S.K., Moteei, N. (2006). Long term water uptake behavior of natural fiber/polypropylene composites, $J$ Appl Polym Sci, 99(5), 2199-2203.

Takase, S., Shiraishi, N. (1989). Studies on composites and polypropylenes, II. J. of Applied Polymer Sci., 37, 645-659.

Tufan, M., Gulec, T., Pesman, E., and Ayrilmis, N. (2016). Technological and Thermal Properties of Thermoplastic Composites Filled with Heat-treated Alder Wood. BioResources, 11(2), 31533164.

Tuong, V.M., and Li, J. (2010). Effect of heat treatment on the change in color and dimensional stability of acacia hybrid wood. Bioresources, 5(2), 1257.

Wolcott, M. P. (2003). Forest Journal, 53, p. 25 .

Woodhams, R. T., Thomas, G., and Rodgers, D. (1984). Wood fibers as reinforcing fillers for polyolefins. Polymer Engineering and Sci., 24(15), 1116-1171.

Yam, K., Gogoi, B., Lai, C., and Selke, S. (1990). Composites from compounding wood fibers with recycled high density polyethylene. Polymer Engineering and Science, 30(11), 693-699.

Zor, M., Tankut, N., Kızıltaş, A., Gardner, D. J., Yazıc1, H., (2016). Feasibility of Using Foamed Styrene Maleic Anhydride (SMA) Co-polymer in Wood Based Composites, Drvna Industrija, 67(4), 399407. 